\title{
A correlation between spiritual level and preoperative patients' anxiety
}

\author{
Herlina Biawan ${ }^{1}$, Jebul Suroso ${ }^{2}$ \\ ${ }^{1,2}$ Department of Nursing, Faculty of Health Sciences, Universitas Muhammadiyah Purwokerto, Indonesia
}

\begin{abstract}
ARTICLE INFO
Article history:

Received: August 9, 2020

Revised: August 20, 2020

Accepted: August 30, 2020

ABSTRACT

Pre-surgery is an action before surgery, which can trigger psychological problems, such as anxiety. Spiritual strength is able to help the individual towards the healing and fulfillment of life goals. The aim of the reseach was discover the correlation between the spiritual level and anxiety in preoperative patients in the surgical inpatient units of RSUD Banyumas. This study was conducted from 12 November to 12 December 2019 in the surgical inpatient units of RSUD Banyumas. This research was a non-experimental quantitative, using a correlational research design with a cross-sectional approach. The sample was selected by purposive sampling technique, with 72 sample respondents. The data collection technique used the HARS (Hamilton Rating Scale Anxiety) and DSES (Daily Spiritual Experience Scale questionnaires) questionnaires. The result found $27.8 \%$ of patients' preoperative anxiety level at RSUD Banyumas did not experience anxiety, 56.9\% felt mild anxiety, and $15.3 \%$ suffered from moderate anxiety. Meanwhile, for the spiritual level, only $1.4 \%$ of the preoperative patients at RSUD Banyumas had a low spiritual level, $52.8 \%$ were at a moderate spiritual level, and $45.8 \%$ presented a high spiritual level. The Spearman Rank statistical test obtained p-value $=0.0001$; the correlation coefficient was -0.469 . There was a correlation between the patients' spiritual level and preoperative anxiety in the surgical inpatient units of RSUD Banyumas.
\end{abstract}

This work is licensed under a Creative Commons Attribution 4.0 International License.

Corresponding Author:

Herlina Biawan,

Department of Nursing, Faculty of Health Sciences,

Universitas Muhammadiyah Purwokerto,

Suparjo Rustam Road KM 7, Purwokerto, 53186, Indonesia.

Email: herlinabiawan@gmail.com

\section{INTRODUCTION}

Science and technology in the health sector are growing rapidly, the options for treating diseases are increasingly diverse, such as surgery. It was estimated that $11 \%$ of the world's disease could be healed by surgery. WHO stated that surgical cases are a public health problem. Based on the National Tabulation Data of the Health Ministry of the Republic of Indonesia in 2009, surgery ranked 11 out of 50 to treat disease patterns in hospitals throughout Indonesia [1]. Surgery is an invasive treatment performed to diagnose or treat diseases, injuries, or body deformities that will injure tissues, cause physiological changes in the body, and affect other organs. Based on the World Health Organization (WHO) data, the number of patients undergoing surgery has increased significantly from year to year. It was recorded that there were 140 million patients in all hospitals in the world in 2011, while 2012 increased into 148 million, for Indonesia even reached 1.2 million people in 2012 [2].

In RSUD Banyumas, 4041 patients obtained surgery in 2017 and increased to 4048 patients in 2018. Based on the surgical patient registration data, the average number of major and minor surgeries in a month was calculated by 50 patients for major operations, 100 patients for minor operations from January to June 2019. From the interview results with preoperative patients in the surgical inpatient units of RSUD Banyumas, 6 out of 10 patients who were going to undergo surgery experienced anxiety. Stated that although surgery is 
considered minor by health professionals, surgery is always considered crucial by patients and their families, which can trigger anxiety.

Anxiety is a feeling of discomfort or vague anxiety with an autonomic response (the source is often not specific or not known by the individual), a feeling of fear caused by dangerous anticipation. It is a signal of alertness that warns individuals to act against threats [3]. Anxiety during the preoperative period is a problem that is often encountered with several postoperative complications. Overall, $61 \%$ of patients had a significant level of preoperative anxiety. Factors that affect the level of preoperative anxiety include gender, level of education, preoperative information, and previous surgical experience. Fear of complications, worry about family, and fear of postoperative pain are the most common factors which result in anxiety before surgery [4]. In a study entitled Prevalence and factor associated with preoperative anxiety among elective surgical patients at the University of Gondar Hospital,concluded that the prevalence of preoperative anxiety was around 59.6\% from 178 patients. Humans consist of physical, emotional, intellectual, social, and spiritual dimensions, where each dimension must be fulfilled. Often the problems that arise in patients when experiencing a condition with certain diseases (e.g. physical illness) result in psychosocial and spiritual problems. When a patient experiences illness, loss, and stress, spiritual strength can help the individual heal and fulfill goals with or through fulfilling spiritual needs [5].

Spirituality is a broad concept with various dimensions and perspectives characterized by a feeling of attachment (connection) to something bigger than ourselves, accompanied by looking for the meaning of life or being described as a universal and touching experience [6]. Ruth Beckmann Murray and Judith Proctor in Krentzman wrote that the spiritual dimension tries to be in harmony with the universe, seeks the answer about the infinity, and comes into focus when a person is facing emotional stress, physical illness, or death. Spirituality becomes a vital element for human life, affecting not only anxiety but also various psychological conditions [7]. Pre-surgery is an action before surgery, which can cause psychological problems, such as anxiety. Spiritual strength is able to assist the individual in healing and fulfillment of goals. Therefore, the authors are interested in observing the correlation between the spiritual level and anxiety in preoperative patients in the Surgical Inpatient Room at RSUD Banyumas.

\section{RESEARCH METHOD}

This research method was a quantitative non-experiment, by correlational research design with a crosssectional approach. This study's sampling was done by purposive sampling method with inclusion criteria for male and female preoperative patients aged 17-55 years. The patients had never had surgery before, fully conscious, and part of an elective surgery program. The number of samples was 72 people. The research instrument employed was HARS questionnaire with 21 questions and a DSES questionnaire with 16 questions. The collected data were then analyzed by univariate and bivariate analysis techniques with the Spearman rank test.

\section{RESULTS AND DISCUSSIONS}

\subsection{Respondents Characteristics}

Table 1. Distributor of Respondents Characteristics $(n=72)$

\begin{tabular}{lcc}
\hline \multicolumn{1}{c}{ Characteristics } & Frequency & Percentage \\
\hline Age & 14 & \\
$17-25$ & 10 & $19,4 \%$ \\
$26-35$ & 27 & $37,9 \%$ \\
$36-45$ & 21 & $29,2 \%$ \\
$46-55$ & & \\
Sex & 33 & $45,8 \%$ \\
Male & 39 & $54,2 \%$ \\
Female & & \\
Surgery type & 39 & $54,2 \%$ \\
$\quad$ Mayor & 33 & $45,8 \%$ \\
Minor & & \\
Education & 2 & $2,8 \%$ \\
$\quad$ No school experience & 24 & $33,3 \%$ \\
Elementary School & 14 & $19,4 \%$ \\
$\quad$ Junior High School & 27 & $37,5 \%$ \\
Senior High School & 5 & $6,9 \%$ \\
$\quad$ University &
\end{tabular}


Based on table 1, it can be understood that the characteristics of preoperative patient respondents at RSUD Banyumas based on the most age category were late adults aged 36-45 years or 27 respondents (37.5\%), the most gender category was women with 39 respondents $(54.2 \%)$, the largest category of surgery was major surgery with 39 respondents $(54.2 \%)$, and the largest education background category was Senior High School with 27 respondents $(37.5 \%)$.

\subsection{Spiritual Level}

Table 2. Frequency Distribution of Spiritual Level $(n=72)$

\begin{tabular}{lcc}
\hline Characteristics & Frequency & Percentage \\
\hline Spiritual Level & & \\
$\quad$ Low & 1 & $1,4 \%$ \\
Moderate & 38 & $52,8 \%$ \\
High & 33 & $45,8 \%$ \\
God Believer & & \\
Impious & 5 & $6,9 \%$ \\
Slightly Pious & 32 & $44,4 \%$ \\
Pious & 18 & $25,1 \%$ \\
Very Pious & 17 & $23,6 \%$ \\
\hline
\end{tabular}

From the table above, it can be seen that only $1.4 \%$ of preoperative patients at RSUD Banyumas had a low spiritual level, the remaining $52.8 \%$ presented a moderate spiritual level, and $45.8 \%$ showed a high spiritual level. The God believer category of pre-surgery patients at RSUD Banyumas illustrated that only $6.9 \%$ were impious, and $44.4 \%$ were slightly pious.

\subsection{Anxiety Level}

Table 3. Frequency Distribution of Anxiety Level Pre-operative anxiety $(n=72)$

\begin{tabular}{lcc}
\hline Characteristics & Frequency & Percentage \\
\hline Without anxiety & 20 & $27,8 \%$ \\
Mild anxiety & 41 & $56,9 \%$ \\
Moderate anxiety & 11 & $15,3 \%$ \\
\hline
\end{tabular}

From the table above, it can be understood that $27.8 \%$ did not experience anxiety, $56.9 \%$ experienced mild anxiety levels, and $15.3 \%$ faced moderate anxiety levels of preoperative patients at RSUD Banyumas.

\subsection{The correlation of spiritual level and anxiety in preoperative patients}

Table 4. The calculation of the Spearman rank Correlation between Spiritual Level and Anxiety in Preoperative Patients in Surgical Inpatient Units at RSUD Banyumas

\begin{tabular}{lccc}
\hline Correlation & $\mathbf{n}$ & $\begin{array}{c}\text { Correlation } \\
\text { Coefficient }\end{array}$ & p-value \\
\hline $\begin{array}{l}\text { spiritual level and anxiety in } \\
\text { preoperative patients }\end{array}$ & 72 & $-0,469$ & 0,0001 \\
\hline
\end{tabular}

Based on the table above, the p-value was 0.0001 , which meant that the p-value was $<0.05$. Thus, Ho was rejected, and Ha was accepted, or there was a correlation between the spiritual level and anxiety in preoperative patients. It could be seen that the strength of the correlation between the spiritual level variable and preoperative patient anxiety was -0.469 or a moderate level of correlation. Therefore, in other words that the higher the patient's spiritual level, the less anxiety patient will be, and the lower the patient's spiritual level, the higher the anxiety patient will be.

\subsection{Respondent characteristics of preoperative patient}

The results revealed that most of the respondents aged 36-45 years were 27 respondents (37.5\%). It supported, which stated a significant correlation between age and anxiety levels. Moreover, this opinion was corroborated [8], that age maturity affected a person in responding to his situation/illness in overcoming the anxiety. Maturity in the adult thinking process was likely to use suitable coping mechanisms than in the children's age group [9]. In this study, most of the respondents were female, with 39 respondents $(54.2 \%)$. In accordance with research, it stated that there was a correlation between gender and the level of preoperative 
patient anxiety [10]. It was confirmed by Mulugeta, which stated that female patients had a statistically higher level of preoperative anxiety than men. However, there was a study that did not present an association between gender and preoperative anxiety.

Here, most respondents were high school educational backgrounds, with 27 respondents (37.5\%). It was confirmed by a research conducted by Bachri [11], which stated that a person's educational status affected the level of anxiety. The education level also affected the awareness and understanding of the stimulus [12]. Notoatmodjo declared that the level of education was one of the factors that influenced patient expectations and perceptions of health services. [13] The results presented that the type of major surgery was 39 respondents (54.2\%). Major surgery was a surgery that involved a wide range of body organs and had a high level of risk to the client's survival. Following the theory presented by Mulugetta, one of the factors that influenced anxiety was the type of surgery proposed.

\subsection{The spiritual level of preoperative patient}

The study results discovered that 38 respondents $(52.8 \%)$ were at a moderate spiritual level.The spiritual level was how individuals understand their existence and experiences. At the data collection of spiritual activity, the respondents who were Pious to God were $44.4 \%$, which meant that they were slightly pious to God. [14] According to the researchers, it was because most respondents only perform their religious obligations when they were healthy. It happened since many respondents did not understand the procedures for worshiping when they were sick. The respondents were afraid because medical instruments such as intravenous drips, urinary catheters had been installed, and some even had NGT installed. They were also concerned that if they did movements for worship, these tools might harm their body. According to Smeltzer and Bare in Diah , anxiety was usually associated with all kinds of unfamiliar procedures that patients must undergo and threats to their life due to surgical procedures. [15]

There were three highest aspects from the total aspect: feeling united and pious to God, appreciation and feeling grateful, and feeling helped. While the three lowest aspects were caring to others, perceiving and feeling God's love, and relationship aspects. According to the researchers' assumption, when he was sick, each individual would ask God for help for his recovery by praying. Praying and worshiping were forms of the servant's closeness to his Lord, and along with the closeness of the servant to his Lord, there would be a feeling of gratitude for His gifts. Spirituality was believed by a person concerning a higher power (God), which raised a need and love for God, and apologies for all mistakes done by praying [16].

Spiritual needs were basic needs required by every human being. If someone was ill, then the relationship with God was getting closer; considering that someone in a sick condition became weak in all respects, no one could raise him from healing unless the Creator [17]. In this study, it was found that aspects of caring for others, perceiving, and feeling God's love and relationships obtained a low value. According to the researcher, it happened because some people thought that pain was a part of a punishment, or people perceived that God did not love him. It was consistent, when people were sick and anxious, they tended to give more attention to themselves than others. [18]

Patients with crises and changes often suffered from disabling symptoms and interfere with the ability to continue their everyday lifestyle. Independence could be seriously threatened, leading to total fear, anxiety, and sadness. Dependence on others for regular self-care could lead to feelings of helplessness and perception of decreased inner strength. A person might feel a loss of life purpose, which affected the inner strength needed to deal with the experienced changes. The strengths of one's spirituality could be an essential factor in how a person dealt with illness changes. Success in overcoming the changes caused by illness could strengthen a person spiritually. Re-evaluation about life is needed. Those who are spiritually healthy would reshape their identity and live within their potential [18].

\subsection{The level of preoperative patient anxiety}

It was understood that 41 respondents $(56.9 \%)$ out of 72 respondents were at mild-level preoperative patients' anxiety. According to Nanda, anxiety was a vague feeling of discomfort or worry accompanied by an autonomic response (the source was often unspecific or unknown to the individual), a feeling of fear caused by dangerous anticipation. It is a sign of alertness that warns individuals from danger and enabled individuals to act against threats. In patients with surgery, the factors which trigger anxiety were factors experienced by individuals, both internal and external. Internal factors were fear of anesthesia, disability, death, fear of pain, fear of losing a job and worry about being the family burden [19]. In comparison, the external factors were fear of the situation in the surgery room, surgery equipment, and health workers [20].

A study at Orthopedic Hospital in Surakarta, 20\% of preoperative patients experienced mild anxiety, and $80 \%$ experienced moderate anxiety [21]. In a study conducted at Mitra Husada Pringsewu Hospital, preoperative patients who were not anxious were $14.3 \%$, experienced mild anxiety $52.4 \%$, moderate anxiety was $28.6 \%$, severe anxiety was $4.8 \%$ [22]. The results of earlier study showed that the anxiety level happened 
to most patients or 31 patients $(67.4 \%)$ who would take elective major surgery in the Surgical Ward of Fatmawati Hospital- Jakarta Selatan, and experienced mild anxiety category. In this study, the anxiety aspect, fear, feelings of depression were the highest aspects. Meanwhile, the aspects of intellectual impairment, gastrointestinal symptoms, and vegetative symptoms were the lowest aspects. Researchers assumed that the symptoms that appeared in respondents were still mild. It was supported by the statement of Gail W, Stuart that mild anxiety was associated with daily tension, the individual's alert, expanded field of perception, and sense sharpens. It could motivate individuals to learn and solved problems effectively and generated creative growth. [23]

\subsection{The correlation of spiritual level and preoperative patient anxiety}

Based on table 4.4, it could be seen that the p-value was 0.0001 , which meant that the p-value $<\alpha$ (0.05), so Ho was rejected. Thus. It can be drawn that there is a correlation between the spiritual level and preoperative patient anxiety. The correlation coefficient value was -0.469 ; it was understood that the correlation strength was moderate. The direction of the correlation between the two variables was not one-way, which meant that the higher the patient's spiritual level, the less anxious he would be, and vice versa.

These findings were following the study conducted by entitled "The effect of spiritual support on anxiety levels in preoperative patients," 16 respondents obtained an average result of anxiety before spiritual support therapy, which was 49.88, with a standard deviation of 6.449. Meanwhile, the average anxiety after spiritual support therapy was 46.81 , with a standard deviation of 6.002 . The statistical test results obtained pvalue $=0.001$, it can be drawn that there is an effect of spiritual support therapy on the level of anxiety in preoperative patients at Imanuel Hospital, Lampung Province. [24]

Anxiety during the preoperative period was a common problem with several postoperative complications. Overall, $61 \%$ of patients had a significant level of preoperative anxiety. Factors that affected the level of preoperative anxiety were gender, level of education, preoperative information, the proposed surgery, and previous surgical experience. Fear of complications, worries about family, and fear of postoperative pain were the most common factors which resulted in anxiety before surgery. Spirituality was a source of motivation and individual emotions regarding one's relationship to God [25]. Spirituality was a vital element in human life, not only affecting anxiety but also various psychological conditions.

\section{CONCLUSION}

Based on the results of the study and the above discussion, the researcher concludes that there is a correlation between the spiritual level and preoperative patient anxiety. It is because the p-value is 0.0001 , which implies that the $\mathrm{p}$-value is $<\alpha(0.05)$, with a correlation coefficient value of -0.469 , which means that the strength of the correlation is moderate.

\section{Acknowledgement}

The research would like to express gratitude to the Director of RSUD Banyumas to permit the researchers to do a study in the surgical inpatient unit of RSUD Banyumas and all employees and patients. They had helped in this research process so that the study can be finished.

\section{REFERENCES}

[1] E. Rahmayati, "Faktor-Faktor Yang Berhubungan Dengan Lama Perawatan Pasien Pasca Operasi Di Ruang Rawat Inap Bedah Rumah Sakit," Jurnal Keperawatan, p. 195, 2017.

[2] T. P. Ningrum, "Gambaran Karakteristik Pasien Wound Dehisence menurut Variabel roterdam di RSUD Kota Bandung," Jurnal Ilmu Keperawatan, pp. 111-115, 2016.

[3] NANDA, Diagnosis Keperawatan., JAKARTA: EGC, 2018.

[4] Mulugeta, "reoperative anxiety and associated factorsamong adult surgical patients in DebreMarkos and Felege Hiwot referral hospitals,Northwest Ethiopia," BMC Anesthesiology, vol. 18, no. 155, pp. 2- 9, 2018.

[5] Iswari, "Pengaruh Kombinasi Terapi Spiritual Deep Breathing Exersice Terhadap Nyeri Dan Kecemasan Pada Pasien Post Operasi Orthopedi Fraktur Nonpatologis. ," Surabaya, 2016.

[6] Ardian, "Konsep Spiritualitas Dan Religiusitas ( Spiritual And Religion) Dalam Konteks Keperawatan Pasien Diabetes Melitus Tipe 2," Jurnal Keperawatan dan Pemikiran Ilmiah, vol. 2, no. 5, pp. 1-9, 2016.

[7] D. H. Barlow, "Psychosocial intervention development for the prevention and treatment of depression: promoting innovation and increasing access," Biological Psychiatry, pp. 610-630, 2002. 
[9] Kuraesin and N. Dewi, "Faktor-Faktor Yang Berhubungan Dengan Tingkat Kecemasan Pasien," FIK UIN Syarif Hidayatullah, Jakarta, 2009.

[10] D. Vellyana, "Faktor-Faktor yang Berhubungan dengan Tingkat Kecemasan pada Pasien," Jurnal Kesehatan, pp. 108-113, 2017.

[11] S. Bachri, Z. Cholid and A. Rochim, "Perbedaan Tingkat Kecemasan Pasien Bedasarkan Usia, Jenis Kelamin, Tingkat Pendidikan dan Pengalaman Pencabutan Gigi Di RSGM FKG Universitas Jember," Universitas Jember, Jember, 2017.

[12] H. Kaplan , Inopsispsikiatri ilmu pengetahuan perilakupsikiatri klinis, 10 ed., vol. 1, Jakarta: Bina Rupa Aksara.

[13] S. Notoatmodjo, Metodologi Penelitian Kesehatan, Jakarta: Rineka Cipta, 2010.

[14] Prameswari, "Hubungan Tingkat Spiritual Dengan Kualitas Hidup Orang Dengan Hiv/Aids Di Yayasan Angel Heart Kota Batam Tahun 2017," Jurnal Psikologi, vol. 1, no. 1, 2018.

[15] D. Setiani, "Identifikasi Tingkat Kecemasan Pre operasi Pasien Fraktur," Jurnal Ilmu Kesehatan, 2017.

[16] A. . H. Aziz, Pengatar Keperawatan, Jakarta: Salemba Medika, 2009.

[17] A. A. Hidayat, Pengantar Konsep Dasar Keperawatan, Jakarta: Salemba Medika, 2008.

[18] Potter and Perry, Fundamental of Nursing, 8th ed., Canada: Elsevier, 2013.

[19] Y. B. Woldegerima, "Prevalence and factor associated with pre operative anxiety among elective surgical patient at University of Gondar Hospita. Gondar Nort west Ethiopia, 2017. A Cross-sectional studyl," International Journal of Surgery Open, pp. 21-29, 2017.

[20] Agusnawati, "Pengaruh terapi spiritual terhadap tingkat ansietas pasien preoperasi elektif di Ruang Bedah RSUD Dr. H. Bob Bazar, SKM Kalianda," Universitas Malahayati, 2013.

[21] A. Maliya and S. Fatimah, "Pengaruh Inhalasi Aromaterapi Mawar Terhadap Tingkat Kecemasan Pada Pasien Pre Operasi Fraktur," Jurnal Ilmiah Permas: Jurnal Ilmiah STIKES Kendal, vol. 9, no. 4, pp. 379-386, 2019.

[22] D. Vellyana, "Faktor-Faktor yang Berhubungan dengan Tingkat Kecemasan pada Pasien," Jurnal Kesehatan, pp. 108-113, 2017.

[23] G. W. Stuart and S. J. Sundeen, Buku Saku Keperawatan Jiwa, 5 ed., Jakarta: EGC, 2006.

[24] Rahmayati, "Pengaruh Dukungan Spritual terhadap Tingkat Kecemasan," Jurnal Kesehatan, pp. 138$142,2018$.

[25] KBBI, Badan Pengembangan dan Pembinaan Bahasa Kementrian Pendidikan dan Kebudayaan, Jakarta, 2016. 